question. And rather than tip-toeing around the sensitivities, the judges of the court - the highest in Europe - trampled right through them. The ECJ had been asked by the German Supreme Court to clarify ambiguous wording in the European Union (EU) directive on the Legal Protection of Biotechnological Inventions, which bans patents on procedures that use human embryos. The ECJ responded with a clumsy ruling that outlaws patents involving stem cells derived from such embryos and, some critics say, raises questions about future research into regenerative medicine (see page 310 ). In doing so, the court effectively stepped over the line that separates the interpretation of law, which is its responsibility, from the creation of law, which is the job of parliaments and governments.

For the most part, the ECJ does a faultless job. This time, however, it exceeded its competence. In the case under consideration, Greenpeace had claimed that the existing directive should outlaw a patent relying on human embryonic stem cells that had been taken out by Oliver Brüstle, director of the Institute of Reconstructive Neurobiology in Bonn, Germany. But are human embryonic stem cells equivalent to human embryos in this context? The German Supreme Court, which was handling the Greenpeace complaint, passed the question up to the ECJ.

Unfortunately, the ECJ chose not to confine its analysis to the patent context, but took it upon itself to define the term 'human embryo' generally (and in the broadest possible way), and to assess the surrounding moral environment. A human embryo, it said, comprises an ovum activated to divide by fertilization or any artificial means. Moreover, it added, any research involving human embryonic stemcell lines is immoral, because such cell lines are originally derived from fertilized eggs.

The ruling left many scientists, judges and legal experts in Germany

and other EU member states fuming. Not only because the court had issued a de facto legal definition of a human embryo, but because it had done so with shoddy reasoning and without appropriate legal references. In the case of ambiguous law, a court should go back and ponder the intention of the law-makers. From its brief justification in Brüstle v. Greenpeace, the ECJ seems not to have done that.

"The ruling left many scientists, judges and legal experts in EU member states fuming."
The ECJ is made up of judges from each EU member state, and critics argue that it simply does not have the technical expertise to deal with issues such as patenting, or stem cells. Yet the court is not held to account by any external watchdog, and its decisions cannot be appealed.

Last week, an alliance of ten major German research organizations, including the German Research Foundation (DFG, the country's national granting agency), the University Rectors Conference and the Max Planck Society, put out a statement condemning the decision. But the damage has been done. Battle lines have already been drawn in the European Parliament, with those opposed to research with human embryonic stem cells calling for funds to be frozen.

The only obvious route out of the confusion created by the ECJ is for the real law-makers - the European Parliament and the Council of the European Union - to amend the ambiguous EU directive that caused all the trouble. They should tighten its loose language on the legal definition of a human embryo in terms of patenting, so that the law reflects what the lawmakers originally intended. This will take courage (and time - the original directive was a decade in the works) but, as the ECJ ruling shows, for all its sensitivities, this is not a subject on which it pays to be vague.

\section{The mask slips}

\section{The Durban meeting shows that climate policy and climate science inhabit parallel worlds.}

$\mathrm{I}$ t says a lot about the outcome of the UN climate talks in South Africa at the weekend that most of the immediate reports focused on the wrangling that led to an agreement of sorts, rather than the contents and implications of the agreement itself. Late-night talks, later-night arguments and early-morning pacts between battling negotiators with the apparent fate of the world resting on their shoulders give the process a melodrama that is hard to resist, particularly for those who experienced it first hand in the chaos of the Durban meeting (see page 299).

Such late finishes are becoming the norm at these summits. Only as nations abandon their original negotiating positions and reveal their true demands - throwing international differences into stark relief - does a sense of urgency develop and serious negotiation take place. Combined with the consensus nature of the talks, which demands that everyone agrees to everything, the result is usually a cobbled-together compromise that allows as many countries as possible to claim victory and, most importantly, provides them with a mandate to reconvene in 12 months' time.

So it was this time. In the search for a successor to the Kyoto Protocol, we now have the Durban Platform, which comes on the heels of the Bali Road Map and the Copenhagen Accord.

It takes a certain kind of optimism - or an outbreak of collective Stockholm syndrome - to see the Durban outcome as a significant breakthrough on global warming, as many are claiming. Outside Europe - which has set itself binding emissions goals over the short and long term beyond what it will inherit under its stated plan to carry on with unilateral cuts under an extended Kyoto - there will be no

obligation for any nation to reduce soaring greenhouse-gas emissions much before the end of the decade. And that is assuming that all flows smoothly in future UN talks, and that a global deal with binding commitments proves easier to find in talks due to start in 2015 than it has so far.

The Durban deal may mark a success in the political process to tackle climate change, but for the climate itself, it is an unqualified disaster. It is clear that the science of climate change and the politics of climate change, which claims to represent it, now inhabit parallel worlds.

This has always been true up to a point, but surely the mask of political rhetoric has now slipped so far, to reveal the ugly political reality underneath, that it can never be replaced. How can politicians talk now with a straight face of limiting global warming to $2{ }^{\circ} \mathrm{C}$ ? How will campaigners frame this result as leaving yet another 'last chance' to save the planet?

That does not make the political process redundant - far from it. Introducing policies to curb emissions was never about saving the planet or not, or stopping global warming or not. It is about damage limitation - the $3^{\circ} \mathrm{C}$ or $4^{\circ} \mathrm{C}$ of average warming the planet could experience in the long term, according to some analyses of the Durban outcome doing the rounds, is clearly much worse than the $2^{\circ} \mathrm{C}$ used as shorthand for dangerous at present. But it is preferable to the $5^{\circ} \mathrm{C}$ or $6^{\circ} \mathrm{C}$ that science suggests is possible if emissions continue to rise unabated.

To prevent that outcome will be just as difficult politically as was the now abandoned attempt to find a global successor in time to follow Kyoto. But it remains possible - and there were at least encouraging signs in Durban that previously obstinate countries recognize that it is necessary, even if it is delayed. Those, including this journal, who have

$\rightarrow$ NATURE.COM To comment online, click on Editorials at: go.nature.com/xhunqv long argued the scientific case for the need to control greenhouse-gas emissions should back this new political mood to the hilt. But as the Durban Platform crowds with politicians, the climate train they wait for has left the station. 